\title{
SIXTEENTH ANNUAL LIST OF PAPERS
}

\author{
READ BEFORE THE AMERICAN MATHEMATICAL SOCIETY AND \\ SUBSEQUENTLY PUBLISHED, INCLUDING REFERENCES \\ TO THE PLACES OF THEIR PUBLICATION.
}

AKERs, O. P. On the Congruence of Axes in a Bundle of Linear Line Complexes. Read Dec. 29, 1905. American Journal of Mathematics, vol. 29, No. 1, pp. 23-47; Jan., 1907.

Allardice, R. E. On a Limit of the Roots of an Equation that is Independent of all but Two of the Coefficients. Read (San Francisco) Feb. 23, 1907. Bulletin of the American Mathematical Society, vol. 13, No. 9, pp. 443-447; June, 1907.

Ames, L. D. Note on the Orientation of a Secant. Read (Southwestern Section) Dec. 1, 1906. Bulletin of the American Mathematical Society, vol. 13, No. 5, pp. 240-241 ; Feb., 1907.

BJerknes, V. F. Experimental Demonstration of Hydrodynamic Action at a Distance. Read Dec. 29, 1905. Included in the author's Fields of Force, New York, 1906.

BuICHFELdT, H. F. On the Order of Linear Homogeneous Groups (Supplementary Paper). Read (Chicago) Apr. 14, 1906. Transactions of the American Mathematical Society, vol. 7, No. 4, pp. 523-529 ; Oct., 1906.

- On Modular Groups Isomorphic with a Given Linear Group. Read (Chicago) Apr. 14, 1906. Transactions of the American Mathematical Society, vol. 8, No. 1, pp. 30-32 ; Jan., 1907.

BuIss, G. A. Note on Maxima and Minima of Functions of Several Variables. Read (Chicago) Dec. 28, 1906. American Mathematical Monthly, vol. 14, No. 3, pp. 47-49 ; Mar., 1907.

The Construction of a Field of Extremals about a Given Point. Read Feb. 23, 1907. Bulletin of the American Mathematical Society, vol. 13, No. 7, pp. 321-324; Apr., 1907.

BolzA, 0. Weierstrass's Theorem and Kneser's Theorem on Transversals for the Most General Case of an Extremum of a Simple Definite Integral. Read Sept. 4, 1906. Transactions of the American Mathematical Society, vol. 7 , No. 4, pp. 459-488; Oct., 1906.

Brenke, W. C. On the Differentiation of Trigonometric Series. Read Apr. 28, 1906. Annals of Mathematics, ser. 2, vol. 8, No. 2, pp. 87-93 ; Jan., 1907.

Carmichaed, R. D. Multiply Perfect Numbers of Three Different Primes. Read Sept. 3, 1906. Annals of Mathematics, ser. 2, vol. 8, No. 1, pp. 4956 ; Oct., 1906.

- On Euler's $\phi$-Function. Read Dec. 28, 1906. Bulletin of the American Mathematical Society, vol. 13, No. 5, pp. 241-243 ; Feb., 1907.

- A Table of Multiply Perfect Numbers. Read Feb. 23, 1907. Bulletin of the American Mathematical Society, vol. 13, No. 8, pp. 383-386; May,1907. 
On a Certain Quartic Curve Which May Degenerate into an Ellipse. Read (Chicago) Mar. 30, 1907. American Mathematical Monthly, vol. 14, No. 3, pp. 52-54; Mar., 1907.

Carver, W. B. Associated Configurations of the Cayley-Veronese Class. Read Sept. 3, 1906. Bulletin of the American Mathematical Society, vol. 13, No. 3, pp. 109-111 ; Dec., 1906.

CoAr, H. L. Functions of Three Real Variables. Read (Chicago) Dec. 29, 1905. American Journal of Mathematics, vol. 28, Nos. 3-4, pp. 243-332; July-Oct. , 1906.

Curtiss, D. R. Sur certains Theorèmes de la Valeur moyenne. Read Sept. 16, 1904. Annals of Mathematics, ser. 2, vol. 8, No. 3, pp. 118-126 ; Apr., 1907.

A Proof of the Theorem Concerning Artificial Singularities. Read (Chicago) Apr. 14, 1906. Annals of Mathematics, ser. 2, vol. 7, No. 4, pp. 161-162; July, 1906.

Dickson, L. E. Linear Algebras in Which Division is Always Uniquely Possible. Read (Chicago) Apr. 14, 1906. Transactions of the American Mathematical Society, vol. 7, No. 3, pp. 370-390; July, 1906.

- Criteria for the Irreducibility of Functions in a Finite Field. Read Sept. 3, 1906. Bulletin of the American Mathematical Society, vol. 13, No. 1, pp. 1-8; Oct., 1906.

- On Commutative Linear Algebras in Which Division is Always Uniquely Possible. Read Sept. 3, 1906. Transactions of the American Mathematical Society, vol. 7, No. 4, pp. 514-522 ; Oct., 1906.

- On the Theory of Equations in a Modular Field. Read Sept. 3, 1906. Bulletin of the American Mathematical Society, vol. 13, No. 1, pp. 8-10; Oct., 1906.

Invariants of Binary Forms under Modular Transformations. Read (Southwestern Section) Dec. 1, 1906. Transactions of the American Mathematical Society, vol. 8, No. 2, pp. 205-232 ; Apr., 1907.

The Symmetric Group on Eight Letters and the Senary First Hypoabelian Group. Read (Chicago) Mar. 30, 1907. Bulletin of the American Mathematical Society, vol. 13, No. 8, pp. 386-389 ; May, 1907.

Eisenhart, I. P. Certain Triply Orthogonal Systems of Surfaces. Read Oct. 28, 1905. American Journal of Mathematics, vol. 29, No. 2, pp. 168212 ; Apr., 1907.

- Applicable Surfaces with Asymptotic Lines of One Surface Corresponding to a Conjugate System of Another. Read Sept. 4, 1906. Transactions of the American Mathematical Society, vol. 8, No. 1, pp. 113-134; Jan., 1907.

Fite, W. B. Irreducible Linear Homogenous Groups Whose Orders are Powers of a Prime. Read Sept. 3, 1906. Transactions of the American Mathematical Society, vol. 8, No.1, pp. 107-112 ; Jan., 1907.

GILLESPIE, D. C. On the Construction of an Integral of Lagrange's Equations in the Calculus of Variations. Read Dec. 29, 1906. Bulletin of the Americun Mathematical Society, vol. 13, No. 7, pp. 345-348; Apr., 1907.

Haskell, M. W. The Resolution of Any Collineation into Perspective Reflections. Read Sept. 22, 1904. Transactions of the American Mathematical Society, vol. 7, No. 3, pp. 361-369 ; July, 1906. 
Haskins, C. N. Note on the Differential Invariants of a Plane. Read Apr. 28, 1906. Transactions of the American Mathematical Society, vol. 7, No. 4, pp. 588-590; Oct., 1906.

HEDRICK, E. R. Note on the Existence of a Continuous First Derivative. Read Aug. 31, 1903. Incorporated in a paper published in the Annals of Mathematics, ser. 2, vol. 7, No. 4, pp. 177-192 ; July, 1906.

- On the Function $\xi(h)$ in the Law of the Mean. Read (Chicago) Apr. 14, 1906. Incorporated in a paper published in the Annals of Mathematics, ser. 2, vol. 7, No. 4, pp. 177-192 ; July, 1906.

- On a Final Form of the Theorem of Uniform Continuity. Read Feb. 23, 1907. Bulletin of the American Mathematical Society, vol. 13, No. 8, pp. 378-380; May, 1907.

Huntington, E. V. Note on the Fundamental Propositions of Algebra. Read Dec. 28, 1905. Incorporated in a paper published in the Annals of Mathematics, ser. 2, vol. 8, No. 1, pp. 1-44; Oct., 1906.

Hutchinson, J. I. On Certain Automorphic Groups Whose Coefficients are Integers in a Quadratic Field. Read Dec. 28, 1905. Transactions of the. American Mathematical Society, vol. 7, No. 4, pp. 530-536 ; Oct., 1906.

- On Loci the Coordinates of whose Points are Abelian Functions of Three Parameters. Read Sept. 3, 1906. Bulletin of the American Mathematical Society, vol. 13, No. 3, pp. 105-109 ; Dec., 1906.

- A Method of Constructing the Fundamental Region of a Discontinuous Group of Linear Transformations. Read Dec. 28, 1906. Transactions of the American Mathematical Society, vol. 8, No. 2, pp. 261-269; Apr., 1907.

Kasner, E. On the Trajectories Produced by an Arbitrary Field of Force. Read April 29, 1905. Transactions of the American Mathematical Society, vol. 7, No. 3, pp. 401-424; July, 1906.

Invariants of Differential Elements for Arbitrary Point Transformation. Read Dec. 28, 1905. American Journal of Mathematics, vol. 28, No. 3, pp. 203-213; July, 1906.

- The Geometry of Dynamical Trajectories. Read September 4, 1906. Transactions of the American Mathematical Society, vol. 8, No. 2, pp. 135158 ; Apr., 1907.

Systems of Extremals in the Calculus of Variations. Read Dec. 29, 1906. Bulletin of the American Mathematical Society, vol. 13, No. 6, pp. 289-292; Mar., 1907.

KerlogG, O. D. The Behavior on the Boundary of Harmonic Functions of a Region. Read Sept. 3, 1906. Bulletin of the American Mathematical Society, vol. 13, No. 4, pp. 168-170 ; Jan., 1907.

LAves, K. A Dynamical Interpretation of an Integral of Jacobi's Partial Differential Equation for the Problem of a Solid Eody Rotating About a Fixed Point. Read (Chicago) Dec. 29, 1905. Astronomische Nachrichten, vol. 171, No. 4095, pp. 225-236; May, 1906.

Lehmer, D. N. On a New Method of Finding Factors of Numbers. Read (San Francisco) Dec. 19, 1903. Bulletin of the American Mathematical Society, vol. 13, No. 10, pp, 501-502; July, 1907. 
- On the Orderly Listing of Substitutions. Read (San Francisco) February 24, 1906. Bulletin of the American Mathematical Society, vol. 13, No. 2, pp. 81-84; Nov., 1906.

Lennes, N. J. On the Necessary Conditions for the Convergence of an Improper Definite Integral. Read (Chicago) Dec. 30, 1904. American Journal of Mathematics, vol. 29, No. 1, pp. 13-22; Jan., 1907.

- On Functions of Limited Variation. Read (Chicago) Apr. 14, 1906. Bulletin of the American Mathematical Society, vol. 13, No. 1, pp. 10-20, and No. 2, p. 87 ; Oct.-Nov., 1906.

Longley, W. R. A Class of Periodic Orbits of an Infinitesimal Body Subject to the Attraction of $n$ Finite Bodies. Read (Chicago) Apr. 14, 1906. Transactions of the American Mathematical Society, vol. 8, No. 2, pp. 159188 ; Apr., 1907.

- Some Particular Solutions in the Problem of $n$ Bodies. Read Dec. 28, 1906. Bulletin of the American Mathematical Society, vol. 13, No. 7, pp. 324-335; Apr., 1907.

McDonald, J. H. The Theory of the Reduction of Hyperelliptic Integrals of the First Kind and of Genus 2 to Elliptic Integrals by a Transformation of the $n$th Order. Read (San Francisco) Feb. 24, 1906. Transactions of the American Mathematical Society, vol. 7, No. 4, pp. 578-587; Oct., 1906.

McKinney, T. E. On the Continued Fractions Representing Properly and Improperly Equivalent Real Numbers in a System of Continued Fractions Depending on a Variable Parameter. Read Dec. 29, 1906. American Journal of Mathematics, vol. 29, No. 3, pp. 213-278; July, 1907.

Manning, W. A. On the Primitive Groups of Class Ten. Read (San Francisco) Feb. 25, 1905. American Journal of Mathematics, vol. 28, No. 3, pp. 226-236 ; July, 1906.

- On Multiply Transitive Groups. Read (San Francisco) Feb. 24, 1906. Transactions of the American Mathematical Society, vol. 7, No. 4, pp. 499508: Oct., 1906.

- A Note on Transitive Groups. Read Sept. 3, 1906. Bulletin of the American Mathematical Society, vol. 13, No. 1, pp. 20-23 ; Oct., 1906.

Mason, M. On the Boundary Value Problems of Linear Ordinary Differential Equations of the Second Order. Read Sept. 7, 1905. Transactions of the American Mathematical Society, vol. 7, No. 3, pp. 337-360; July, 1906.

- Curves of Minimum Moment of Inertia. Read Dec. 29, 1905. Annals of Mathematics, ser. 2, vol. 7, No. 4, pp. 165-172; July, 1906.

- A Necessary Condition for an Extremum of a Double Integral. Read Apr. 28, 1906. Bulletin of the American Mathematical Society, vol. 13, No. 6 , pp. 293-298 ; Mar., 1907.

— Selected Topics in the Theory of Boundary Value Problems of Differential Equations. Four Lectures. Read Sept. 5-8, 1906. Bulletin of the American Mathematical Society, vol. 13, No. 5, pp. 223-231; Feb., 1907.

MrLueR, G. A. Groups in Which Every Subgroup of Composite Order is Invariant. Read (San Francisco) Feb. 24, 1906. Archivder Mathematik und Physik, ser. 3, vol. 11, No. 1, pp. 76-79 ; Nov., 1906. 
- Generalization of the Groups of Genus Zero. Read Sept. 4, 1906. Transactions of the American Mathematical Society, vol. 8, No. 1, pp. 1-13; Jan., 1907.

Groups of Order $p^{m}$ Containing Exactly $p+1$ Abelian Subgroups of Order $p^{m-1}$. Read Oct. 27, 1906. Bulletin of the American Mathematical Society, vol. 13, No. 4, pp. 171-177 ; Jan., 1907.

The Groups in Which Every Subgroup is Either Abelian or Hamiltonian. Read Oct. 27, 1906. Transactions of the American Mathematical Society, vol. 8, No. 1, pp. 25-29; Jan., 1907.

- Groups in Which Every Subgroup is Either Abelian or Dihedral. Read (Southwestern Section) Dec. 1, 1906. American Journal of Mathematics, vol. 29, No. 3, pp. 289-294; July, 1907.

- On the Minimum Number of Operators whose Orders Exceed Two in any Finite Group. Read Dec. 29, 1906. Bulletin of the American Mathematical Society, vol. 13, No. 5, pp. 235-239; Feb., 1907.

- The Groups Generated by Three Operators Each of Which is the Product of the Other Two. Read Feb. 23, 1907. Bulletin of the American Mathematical Society, vol. 13, No. 8, pp. 381-382; May, 1907.

- Note on the Commutator of Two Operators. Read April 27, 1907. Bulletin of the American Mathematical Society, vol., 13, No. 10, pp. 497501 ; July, 1907.

Moore, C. L. E. Geometry of Circles Orthogonal to a Given Sphere. Read Dec. 28, 1905. Annals of Mathematics, ser. 2, vol. 8, No. 2, pp. 57-72; Jan., 1907.

Moore, C. N. On the Introduction of Convergence Factors into Summable Series and Summable Integrals. Read Feb. 23, 1907. Transactions of the American Mathematical Society, vol. 8, No. 2, pp. 299-330; Apr., 1907.

Moore, E. H. The Decomposition of Modular Systems Connected with the Doubly Generalized Fermat Theorem. Read (Chicago) Dec. 29, 1898. Bulletin of the American Mathematical Society, vol. 13, No. 6, pp. 280-288; Mar., 1907.

- Note on Fourier's Constants. Read (Southwestern Section) Dec. 1, 1906. Bulletin of the American Mathematical Society, vol. 13, No. 5, pp. 232-234; Feb., 1907.

Morley, F. Reflexive Geometry. Read Sept. 4, 1906. Transactions of the American Mathematical Society, vol. 8, No. 1, pp. 14-24; Jan., 1907.

Monris, R. On the Expressibility of the Automorphic Functions of the Group $\left(0,3 ; l_{1}, l_{2}, l_{3}\right)$ in T'erms of Theta Series. Read Sept. 7, 1905. Transactions of the American Mathematical Society, vol. 7, No. 3, pp. 425448 ; July, 1906.

Moulton, F. R. A Class of Periodic Solutions of the Problem of Three Bodies. Read Sept. 8, 1905. Transactions of the American Mathematical Society, vol. 7, No. 4, pp. 537-577 ; Oct., 1906.

On the Classes of Periodic Orbits Computed by G. H. Darwin. Read (Chicago) April 14, 1906. Transactions of the American Mathematical Society, vol. 7, No. 4, pp. 537-577; Oct., 1906. 
OsGood, W. F. The Calculus in our Colleges and Technical Schools. [Presidential Address.] Read Apr. 27, 1907. Bulletin of the American Mathematical Society, vol. 13, No. 9, pp. 449-467 ; June, 1907.

PeIrce, G. A New Approximate Construction for $\pi$. Read Dec. 29, 1905. Bulletin of the American Mathematical Society, vol. 13, No. 4, pp. 166-167; Jan., 1907.

Prerpont, J. On the Area of Curved Surfaces. Read Apr. 28, 1906. Transactions of the American Mathematical Society, vol. 7, No. 4, pp. 489498 ; Oct., 1906.

Ragsdale, Virginia. On the Arrangement of the Real Branches of Plane Algebraic Curves. Read Apr. 29, 1905. American Journal of Mathematics, vol. 28, No. 4, pp. 377-404; Oct., 1906.

Ravum, A. The Group of Classes of Congruent Matrices and its Application to the Group of Isomorphisms of any Abelian Group. Read Sept. 3, 1906. Transactions of the American Mathematical Society, vol. 8, No. 1, pp. 71-91 ; Jan., 1907.

On Jordan's Linear Congruence Groups. Read Oct. 27, 1906. Bulletin of the American Mathematical Society, vol. 13, No. 7, pp. 336-345: Apr., 1907.

Richardson, R. G. D. Multiple Improper Integrals. Read Dec. 28, 1905. Transactions of the American Mathematical Society, vol. 7, No. 3, pp. 449458 ; July, 1906.

Richardson, Sophia F. Note on Poristic Systems of Polygons. Read Oct. 27, 1906. Bulletin of the American Mathematical Society, vol. 13, No. 4, pp. 177-182 ; Jan., 1907.

Saurex, P. L. On the Distance from a Point to a Surface. Read April 27, 1907. Bulletin of the American Mathematical Society, vol. 13, No. 9, pp. 447-448; June, 1907.

Schweitzer, A. R. Concerning Abstract Geometrical Relations. Read Sept. 3, 1906. Bulletin of the American Mathematical Socrety, vol. 13, No. 2, pp. 79-81; Nov., 1906.

Scott, Charlotte A. Note on Regular Polygons. Read Oct. 27, 1906. Annals of Mathematics, ser. 2, vol. 8, No. 3, pp. 12 7-134; Apr., 1907.

SEe, T. J. J. On the Physical State of the Matter of the Earth's Interior, with Considerations on Terrestrial Geology, and on the Comparative Geology of the Other Planets. Read (San Francisco) Feb. 25, 1905. Astronomische Nachrichten, vol. 169, No. 4053, pp. 321-364 ; Oct., 1905.

Sisam, C. H. On Septic Scrolls. Read Dec. 29, 1904. American Journal of Mathematics, vol. 29, No. 1, pp. 48-100 ; Jan., 1907.

Smith, Clara E. A Theorem of Abel and its Application to the Development of an Arbitrary Function in Terms of Bessel's Functions. Read Dec. 29, 1905. Transactions of the American Mathematical Society, vol. 8, No. 1, pp. 92-106; Jan., 1907.

- Development of a Function in Terms of Bessel's Functions (Second Paper). Read Feb. 24, 1906. Transactions of the American Mathematical Society, vol. 8, No. 1, pp. 92-106 ; Jan., 1907.

Snyder, V. On a Type of Rational Twisted Curves. Read Sept. 8, 1905, American Journal of Mathematics, vol. 28, No. 3, pp. 237-242; July. 1906. 
- On Twisted Curves Contained in a Linear Complex. Read April 28, 1906. American Journal of Mathematics, vol. 29, No. 3, pp. 279-288; July, 1907.

Stickelberger, L. Zur Theorie der vollständig reduciblen Gruppen, die zu einer Gruppe linearer homogener Substitutionen gehören. Read Sept. 3, 1906. Transactions of the American Mathematical Society, vol. 7, No. 4, pp. 509-513; Oct., 1906.

Story, W. E. Denumerants of Double Differentiants. Read Dec. 29, 1906. Transactions of the American Mathematical Society, vol. 8, No. 1, pp. 33-70; Jan., 1907.

VAN Vleck, E. B. A Proof of Some Theorems on Pointwise Discontinuous Functions. Read Oct. 29, 1904 . Transactions of the American Mathematical Society, vol. 8, No. 2, pp. 189-204; Apr., 1907.

- Some Theorems of Pointwise Discontinuous Functions ; Supplementary Note. Read Apr. 29, 1905. Published with the previous paper.

White, H. S. Poncelet Quadrilaterals on a Curve of the Third Order and a Conic. Read Oct. 28, 1905. Annals of Mathematics, ser. 2, vol. 7, No. 4, pp. 172-176; July, 1906.

Wilczynski, E. J. Projective Differential Geometry of Plane Curves. Read (San Francisco) Feb. 25, 1905. Included in Chapter 3 of the Author's Projective Differential Geometry of Curves and Ruled Surfaces, Leipzig, 1906.

Projective Differential Geometry. Read Apr. 29, 1905. Incorporated in the paper of Feb. 24, 1906 (see below).

- On a System of Partial Difterential Equations in Involution. Read (San Francisco) Sept. 30, 1905. Incorporated in the paper of Feb. 24, 1906 (see below).

- Outline of a Differential Projective Geometry of Curved Surfaces. Read (San Francisco) Feb. 24, 1906. Transactions of the American Mathematical Society, vol. 8, No. 2, pp. 233-260; Apr., 1907.

- Projective Differential Geometry. Four Lectures. Read Sept. 5-8, 1906. Bulletin of the American Mathematical Society, vol. 13, No. 3, pp. 102-105; Dec., 1906.

Wirson, E. B. On Divergence and Curl. Read Sept. 4, 1906. American Journal of Science, ser. 4, vol. 23, No. 135, pp. 214-220 ; Mar., 1967.

Oblique Reflections and Unimodular Strains. Read Sept. 4, 1906. Transactions of the American Mathematical Society, vol. 8, No. 2. pp. 270298 ; Apr., 1907. See also Annals of Mathematics, ser. 2, vol. 8, No. 2, pp. 77-86; Jan., 1907.

- On the Revolutions of a Dark Body about the Sun. Read Feb.23, 1907. Annals of Mathematics, ser. 2, vol. 8, pp. 135-148; Apr., 1907.

Wright, J. E. Correspondences and the Theory of Continuous Groups Read Dec. 29, 1905. Transactions of the American Mathematical Society, vol. 7, No. 3, pp. 391-400; July, 1906.

- Arrangement of Ovals of a Plane Sextic Curve. Read Apr. 27, 1907. American Journal of Mathematics, vol. 29, No. 3, pp. 305-308; July, 1907.

Young, J. W. On a Class of Discontinuous $\zeta$-Groups Defined by Normal Curves of the Fourth Order in a Space of four Dimensions. Read (Chicago) Dec. 29, 1905. Rendiconti del Circolo Matematico di Palermo, vol. 23, No. 1, pp. 97-106; Jan.-Feb., 1907. 